\title{
Design and development of pelton wheel for pico-hydro power generation unit
}

\author{
SEEMA V. AWARE*, VIJAY V. AWARE, SAMEL KUSHAL AND PUJA PACHBHAI \\ College of Agricultural Engineering and Technology, Dapoli, RATNAGIRI (M.S.) INDIA
}

\begin{abstract}
The smallest hydroelectric systems, with power generation below $5 \mathrm{~kW}$ is termed as pico-hydro power. The Konkan region of the Maharashtra state, receives a very heavy rainfall, to the tune of 3000 to $4500 \mathrm{~mm}$ from June to September. Due to high intensity, duration and frequency of the rainfall, the electricity transmission lines get damaged due to falling of trees or bad weather. The rainwater which falls on the roof tops of the houses has a great pico-scale hydroelectric potential. This rainwater, which falls on roof tops possesses the potential energy. If this water is made to fall on a turbine with a high velocity, electricity can be generated. Houses in Konkan region, having an average height of $8 \mathrm{~m}$, or more (ground floor, first floor and roof) and assuming a roof water collection area of about $10 \times 10 \mathrm{~m}$; by calculation, it is observed that, there is a potential to generate about 50 to $60 \mathrm{~W}$ of hydro power. This power can lit four to five LED lights of $10 \mathrm{~W}$ capacities each.
\end{abstract}

Key Words : : Design, Development, Pelton wheel, Pico-hydro power, Generation unit

View Point Article : Aware, SeemaV., Aware, Vijay V., Kushal, Samel and Pachbhai, Puja (2016). Design and development of pelton wheel for pico-hydro power generation unit. Internat. J. agric. Sci., 12 (1) : 60-64.

Article History : Received : 10.11.2015; Revised : 27.11.2015; Accepted : 09.12.2015 